\title{
RESEARCHPAPER
}

\section{Stability analysis for pod yield and its component traits in groundnut (Arachis hypogaea L.)}

\author{
A. S. MINDE ${ }^{1}$, M. S. KAMBLE ${ }^{1}$ AND R. M. PAWAR ${ }^{2}$ \\ ${ }^{1}$ Division of Agricultural Botany, College of Agriculture, KOLHAPUR (M.S.) INDIA \\ (Email: murlikamble5@gmail.com) \\ ${ }^{2}$ Department of Agricultural Botany, BharatiVidyapeeth's Loknete Mohanrao Kadam College of Agriculture, \\ Kadegaon, SANGLI (M.S.) INDIA (Email: ranveer_1972@ rediffmail.com) \\ Email : atharv_2005@rediffmail.com
}

Article Info : Received : 12.11.2016; Revised : 10.03.2017; Accepted : 21.03.2017

Ten groundnut genotypes were evaluated to know the role of $\mathrm{G} x \mathrm{E}$ interaction and also to study stability performance over three environments. Analysis of variance revealed highly significant differences among the genotypes for all the characters studied. Genotypes $\mathrm{x}$ environment interactions were significant for all the characters under study indicating influence of environmental conditions.Stability analysis showed that both linear and non-linear components of $\mathrm{G} x \mathrm{E}$ interactions were highly significant for all the characters. Environment $\left(\mathrm{E}_{1}\right)$ was observed to be most suitable for better expression of yield and its contributing characters. None of the genotype was found to be average stable for all the characters. Of all the genotypes, JL-24 and Phule Unnati for fresh pod yield/plant and TPG-41 and JL-24 for dry pod yield/plant exhibited average stabilityacross the environments.

Key words : Groundnut, Arachis hypogaea, G x E interaction, Stability, Pod yield

How to cite this paper : Minde, A.S., Kamble, M.S. and Pawar, R.M. (2017). Stability analysis for pod yield and its component traits in groundnut (Arachis hypogaea L.). Asian J. Bio. Sci., 12 (1) : 15-20.DOI : 10.15740/HAS/AJBS/12.1/15-20. 